\title{
雛における血清ビテリン産生能と実用形質との 関係ならびにその育種的見解
}

\author{
山本興三郎・山岸耕一・河野憲太郎・樋浦善敬 \\ 新潟大学農学部 新潟市, 950-21
}

エストロジェン投与雛における血清ビテリン産生能に 関連して, 従来いくつかの報告を行なってきた。しかし ながら，血清ビテリン産生能が産卵鶏における実用的な 形質に対してどのような関連性を有し，またどのような 意義を有するものであるかについでは，現在までほとん ぞ報告しておらず，また他にもその報告をみない。筆者 らは, 従来免疫的手法によって表現して来た血清ビテリ ン反店回帰係数 $b$ に代る簡便な指標として考案した血清 のアセトン処理による濁度から算出した回帰係数 $\boldsymbol{b}^{\prime \mathbf{1}}$ を 用い，それが産卵成縝，卵重，体重および初单日齢等の 尖用形質といかなる開係にあるか丧明らかに与るため，

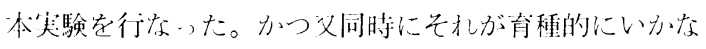

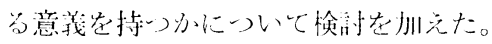

\section{材料および方法}

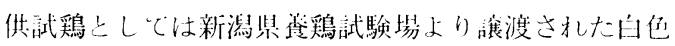
レグホーン㮔の) Rapp, Forsgate, Thornber, Garber 0) 4 系統の雌雉を用いた（以下それぞれ Ra, Fo, Th, G 系 と略称する)。

これらの矱は各系統とも 2 力年にわたり, 各系統ごと に初年度䄪 50 羽, 次年度約 30 羽と分飼し, 合計 327 羽 を使用した。血清ビテリン産生能は彷来の報告と同様に 60 日齢よりエストロジェン投与を 10 日間行ない，その 間逨日採血して血清のアセトン沈でえによる渴度の測定 を行ない，個体ごとに回帰係数故を算出した。これらの 嗮住初産開始後 4 力月間の産卵記録が得られるまで飼消 したが，余中擎死したもの，事故鶏等を除くと完全な䛉 錄の得られたものは全体で 245 羽であった。

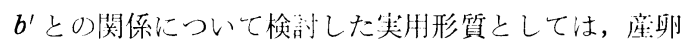
鵎の资質として特に重要と思われる300 日龄時卵重,

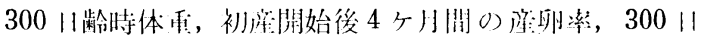

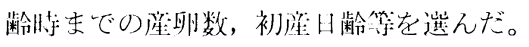

なおこのほか, 笑験鷄の初産開始までの死亡数, 初産

昭和 52 年 3 月 5 日受付
開始後 4 力月までの産卵調査期間に打ける死亡数等につ いて調べ，その結果についても検討を加えた。

\section{結果}

第 1 表は $b^{\prime}, 300$ 日齢卵重，300日齢体重，初産開始 後 4 ケ月間に打ける産卵率, 300 日齢までの産卵数およ び初産日齢（以下略してそれぞれ卵重, 体重, 産卵率, 産卵数，初産日齢という）について最小自乗分析を行な い，得られた最小自乘平均值と標準誤差を各系統別に表

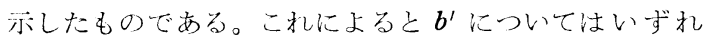
の采統に沶いてもほぼ似通った值定示しているが，他の 形質については系統により多少異ないた数值を示してい る0が羿められる。そこでこれらの最小目乘平均值にの

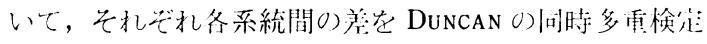
法によーて比較したよこつ（第 2 衣)，故に一いては条

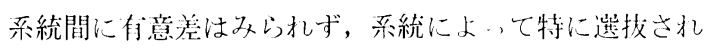
た形の偏りは㥸められない。しかし，それ以外の形質で は采統間にそれぞれ有意差がみられ，卵重では Ra 系の みが他の 3 系に比べ有意に軽く, 体重では Fo, Th の 2 系統間には差はみられないが $\mathrm{G}$ 采がもっとも重く $\mathrm{Ra}$ 系 はもっとも軽い。この両系はまた他のいら゙れの系統との 阔にも有意差がみられた。4 ケ月間産卵率については G 系のみが他の 3 系統に比べ有意に低く, 300 日歯交をでの 産卵数についてもほぼ同様な傾向がみられた。初産日龄 については Th 系のみが他の 3 系統に比べ有意に早く, 次いで Ra, G 系で最も晚いのは Fo 采であった。

次にこ机らの諸形質間の相関を共分散分析によって求 めると第 3 表-1の上うになり, 体重, 卵重, 初産日龄は $b^{\prime}$ との閒にそれぞれ有意な相関が㴓められた。しかし ながら産卵率，商卵数については有意な関倸は得られ

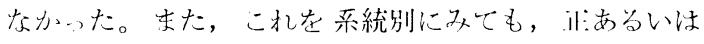
自の有意な相関を小したり，あるいはきわ的て低い相関 が得られるなど一定の傾向は㥸められなかった。そのほ か, 体重と卵重, 体重と産卵数, 産卵数と初産日齢およ び産卵率と産卵数の閒にはそれぞれ有意な相関が認めら 
表 1. $b^{\prime} ， 300$ 日齢時卵重，300日齡時体重，初産開始後 4 ケ月間産卵率， 300 日齢時までの産卵数および初産日齢の最小自乗平均值と標準誤差

Table 1. Least square means and standard errors of the $b^{\prime}$, the egg and the body weights at 300 days of age, the rates of egg laying for 4 months after the first egg and the numbers of egg laying to 300-day old

\begin{tabular}{|c|c|c|c|c|c|c|}
\hline Strain & $b^{\prime}$ & E. W. & B. W. & R. E. L. & No. Egg & A. F.E. \\
\hline \multirow[t]{2}{*}{$\mathrm{Ra}$} & 3.035 & 54.82 & 1.624 & 51.33 & 66.17 & 192.91 \\
\hline & \pm 0.179 & \pm 0.49 & \pm 0.026 & \pm 1.48 & \pm 3.18 & \pm 3.15 \\
\hline \multirow[t]{2}{*}{ Fo } & 2.939 & 56.20 & 1. 744 & 50.87 & 57.48 & 205.48 \\
\hline & \pm 0.192 & \pm 0.52 & \pm 0.028 & \pm 1.59 & \pm 3.42 & \pm 3.39 \\
\hline \multirow[t]{2}{*}{$\mathrm{Th}$} & 3.094 & 55.33 & 1.748 & 54.44 & 73.08 & 184.72 \\
\hline & \pm 0.200 & \pm 0.54 & \pm 0.029 & \pm 1.65 & \pm 3.56 & \pm 3.53 \\
\hline \multirow[t]{2}{*}{ G } & 2.829 & 56.94 & 2. 006 & 42.11 & 47.15 & 196.51 \\
\hline & \pm 0.209 & \pm 0.57 & \pm 0.030 & \pm 1.73 & \pm 3.72 & \pm 3.69 \\
\hline
\end{tabular}

E. W. : Egg Weight, B.W.: Body Weight, R.E.L.: the Rate of Egg Laying, No. Egg: the Number of Egg Laying, A.F.E.: the Age at First Egg.

The rate of egg laying (\%) was transformated to the angle whose sine is the square root of percentage $($ Angle $=\arcsin \sqrt{\%})$

表 2. 諸形質平均值の差に関する Duncan の 同時多重検定

Table 2. Duncan's multiple range tests for the differences of mean values of various traits in each strain

\begin{tabular}{lcccc}
\hline & $\mathrm{G}$ & $\mathrm{Fo}$ & $\mathrm{Ra}$ & $\mathrm{Th}$ \\
$b^{\prime}$ & 2.829 & 2.939 & 3.035 & 3.094 \\
\cline { 2 - 5 } & $\mathrm{Ra}$ & $\mathrm{Th}$ & $\mathrm{Fo}$ & $\mathrm{G}$ \\
E. W. & 54.82 & 55.33 & 56.20 & 56.94 \\
\cline { 2 - 5 } & $\mathrm{Ra}$ & $\mathrm{Fo}$ & $\mathrm{Th}$ & $\mathrm{G}$ \\
B. W. & 1.624 & 1.744 & 1.748 & 2.006 \\
& $\mathrm{G}$ & $\mathrm{Fo}$ & $\mathrm{Ra}$ & $\mathrm{Th}$ \\
R. E. L. & 42.11 & 50.87 & 51.33 & 54.44 \\
& $\mathrm{G}$ & $\mathrm{Fo}$ & $\mathrm{Ra}$ & $\mathrm{Th}$ \\
No. Egg & 47.15 & 57.48 & 66.17 & 73.08 \\
& $\mathrm{Th}$ & $\mathrm{Ra}$ & $\mathrm{G}$ & $\mathrm{Fo}$ \\
A. F. E. & 184.72 & 192.91 & 196.51 & 205.48 \\
\hline
\end{tabular}

Ra, Fo, Th, G: Strain

Values Presented above are least square means in each strain as seen in table 1

れた。そこで尚との間に有意な相関関係の誌められた 卵重，体重抢よび初産日系について相出の偏相関を求め てタると第 3 表-2 に示すように， $b^{\prime}$ と体重または初産 日歯との間には単純相関の場合と同様有意な相関が認め られたが， b'と卵重との間の偏相関は極めて低くなり有
意性核められなくなった。また率重と体重の閒にも単 純相関の場合と同様有意な偏相関が郘められたが，この 事は単純相関でみられた $b^{\prime}$ と卵重の間の有意な相関が 体重の变動に伴なって得られたものである事を赤してい ๖。

普通 2 変量間の相関をみた場合，第 1 図の模式鿾のよ うな分布像を示すことが一般には考えられている。今回 の結果でも $b^{\prime}$ と体重および卵重等との間にほぼこれに 類似した関係が䜑められたのに対し， $b^{\prime}$ と産卵率の場合 は全くこれと異なった様相を示していた。すなわち第 4

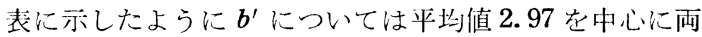

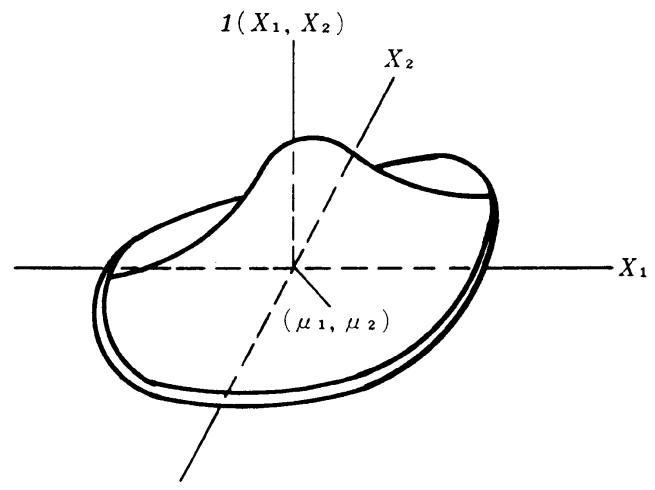

议 1.2 変量間相関の模式図

Fig. 1. The artificial model in bivariate correlation 
表 3-1. 諸 形 質 間 の 相 関

Table 3-1. Correlations among various traits

\begin{tabular}{cccccc}
\hline & B. W. & E. W. & No. Egg & A. F. E. & R. E. L. \\
\hline$b^{\prime}$ & $-0.292^{* * *}$ & $-0.144^{*}$ & 0.028 & $-0.138^{*}$ & -0.064 \\
& B. W. & $0.282^{* * *}$ & 0.131 & 0.030 & 0.041 \\
& & E. W. & -0.016 & 0.071 & 0.014 \\
& & No. Egg & $-0.527^{* * *}$ & $0.757^{* * *}$ \\
& & & A. F. E. & 0.051
\end{tabular}

*: Significant at $5 \%$ level

***: Significant at $0.1 \%$ level

表 3-2. $b^{\prime}, 300$ 日齢時卵重，300日齢時 体重, 初産日齿會間の偏相関

Teble 3-2. Partial correlations among the $b^{\prime}$, the egg weight, the body weight and the age at first egg

\begin{tabular}{cccc}
\hline & E. W. & B. W. & A. F. E. \\
\hline \multirow{6}{*}{$b^{\prime}$} & -0.059 & $-0.269^{* * *}$ & $-0.132^{*}$ \\
& E. W. & $0.255^{* * *}$ & 0.057 \\
& & B. W & -0.025
\end{tabular}

*: Significant at $5 \%$ level

$* * *$ : Significant at $0.1 \%$ level
側にほぼ坛称な分们を示していた。しかしながら座卯率 については平均値 $69.64 \%$ 以下 $3 \%$ の範囲まできわめて なだらかな分布状態を示しているのに対し，69\%超え $75 \%$ を境としてそれ以上の高産卵率を示与個体の忺現頻 度は激減しているのが涊められた。计規性の検走絬果か らも拉よそ正規分布とは見なされない程分布の偏りが大 きくなっている。これについてステレオグラムを作成し た結果, 写真 1 のように産卵率 $75 \%$ 以上のところで断 崖状に出現頻度が低下しており $b^{\prime}$ の平均值を中心とし た区域に 80 \%以上の高産卵率を寺す個体がわずかなが ら観察された。

また試験鶏の中には産卵開始前に死亡した鶏，産卵開 始後に死亡した鷄が出現したが，それらの結果について

表 4. $b^{\prime}$ と初産開始後 4 ケ月間産卵率の頻度分布

Table 4. Frequency distribution of the $b^{\prime}$ and the rate of egg laying for 4 months after the first egg

\begin{tabular}{|c|c|c|c|c|c|c|c|c|c|c|c|c|c|c|}
\hline R. & $\begin{array}{r}3.0 \\
(10)\end{array}$ & $\begin{array}{l}11.7 \\
(20)\end{array}$ & & $\begin{array}{l}25.0 \\
(30) \\
\end{array}$ & & $\begin{array}{l}41.3 \\
(40)\end{array}$ & & $\begin{array}{l}58.7 \\
(50) \\
\end{array}$ & & $\begin{array}{l}75.0 \\
(60)\end{array}$ & & $\begin{array}{l}88.3 \\
(70)\end{array}$ & $\begin{array}{l}(\%) \\
(\operatorname{arc}\end{array}$ & $\sin \sqrt{ } \%)$ \\
\hline$b^{\prime}$ & & & & & & & & & 1 & 3 & & & & \\
\hline \multirow[t]{2}{*}{1} & & & & 1 & & 1 & 1 & 1 & 2 & 2 & 2 & 1 & & \\
\hline & & & & 1 & 1 & 2 & 2 & 6 & 3 & 2 & 2 & 3 & & \\
\hline \multirow[t]{2}{*}{2} & 1 & & 1 & 1 & 1 & 4 & 3 & 1 & 8 & 7 & 3 & 1 & & \\
\hline & & & 1 & 2 & 1 & & 2 & 4 & 5 & 11 & 3 & 1 & & \\
\hline \multirow[t]{2}{*}{3} & 1 & & 1 & 1 & 3 & 2 & 4 & 2 & 4 & 11 & 4 & & & \\
\hline & & & & 4 & 5 & 3 & 1 & 4 & 5 & 13 & 9 & 2 & & 1 \\
\hline \multirow[t]{2}{*}{4} & & & & & 2 & 2 & 2 & 1 & 2 & 2 & 5 & & & \\
\hline & & 1 & 1 & 2 & & 2 & 3 & 1 & 1 & 3 & & 1 & & \\
\hline \multirow[t]{2}{*}{5} & & & 1 & & & 3 & 3 & & 1 & 3 & 3 & & & \\
\hline & & & 1 & 1 & & 1 & 1 & & 2 & 1 & 1 & 1 & & \\
\hline \multirow[t]{2}{*}{6} & & & & & & & & 2 & & 3 & 2 & & & \\
\hline & & & & & & & & & & 3 & & & & \\
\hline \multicolumn{15}{|l|}{7} \\
\hline & & & & & & & & & & 1 & & & & \\
\hline 8 & & & 1 & & & & & & & 1 & & & & \\
\hline
\end{tabular}




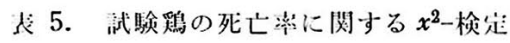

Table 5. Chi-square test for the mortality of hens

\begin{tabular}{ccccc}
\hline & M. B.E. L. & M. A.E. L. & No. Surv. & Sum \\
\hline M. L. M. $b^{\prime}$ & 37 & 13 & 128 & 178 \\
& $(20.8) \%$ & $(7.3)$ & $(71.9)$ & $(100)$ \\
M. M. M. $b^{\prime}$ & 14 & 13 & 117 & 144 \\
& $(9.7) \%$ & $(9.0)$ & $(81.3)$ & $(100)$ \\
H.t & 51 & 26 & 245 & 322 \\
\hline$x^{2}$ & $6.15^{*}$ & 0.29 & 0.91 & 3.59 \\
\hline & & & $*$ : Significant at & $5 \%$ level \\
& Total & $x^{2}=7.358^{* *}$ & $* *$ Significant at & $1 \%$ level
\end{tabular}

M.B.E. L.: Mortality before the biginning of egg laying

M.A.E.L.: Mortality after the biginning of egg laying

No. Surv.: Number of survivors

M.L.M. $b^{\prime}$ : Mortality in less than mean value of $b^{\prime}$

M. M.M. $b^{\prime}$ : Mortality in more than mean value of $b^{\prime}$

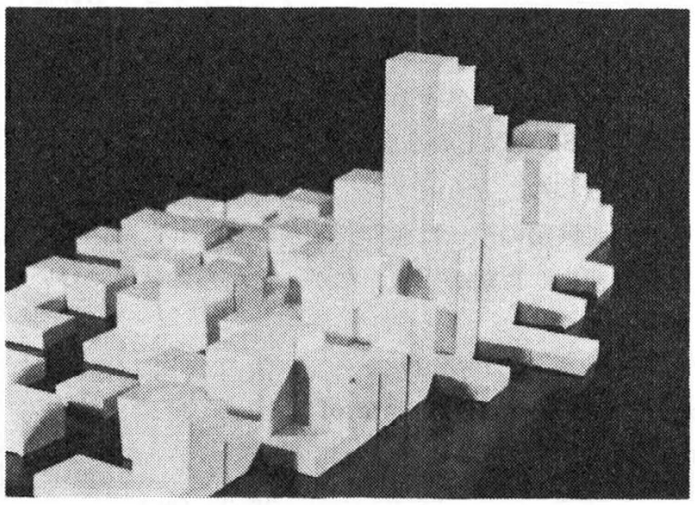

写真 1. $b^{\prime}$ および産卵率の頻度分们のステ レオグラム

Photo. 1. Stereogram on the frequency distribution of the $b^{\prime}$ and the rate of egg laying

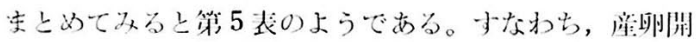
始前に死亡したもので $b^{\prime}$ が平均佰以下の湖体数法全体 178 羽中 37 羽で $20.8 \%$ と最も多く， $b^{\prime}$ が屹值以上の

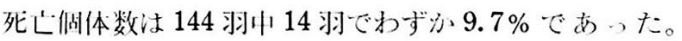

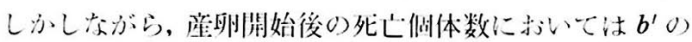

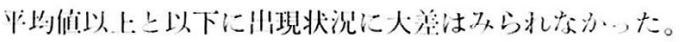

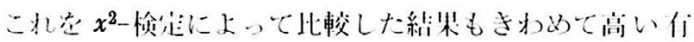

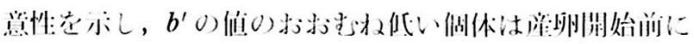

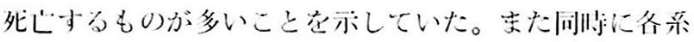
統别に死亡做体のみについての $\boldsymbol{b}^{\prime}$ の平均值学算出して みたところ各系統とも全平均を下回っているのが羿めら れた。

\section{考 察}

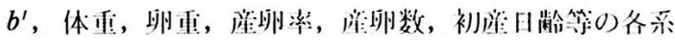

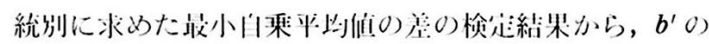

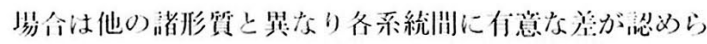

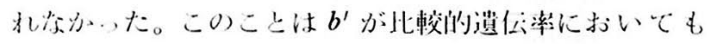

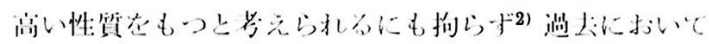

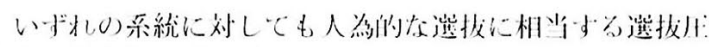

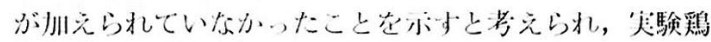

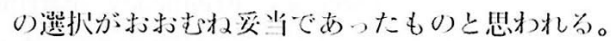

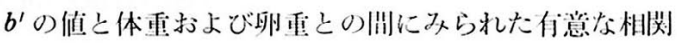
䦌係の中， $b^{\prime}$ と体重との閘係は $b^{\prime}$ と卵重との間に方 れる相刘䦌係よりさらに密なもので直接的な网係にある ことが，第 3 装-2にホした偏相閏の結果からも明らか

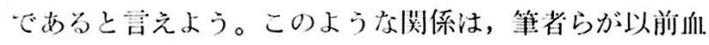
清ビテリン度回州係数 $b$ にいて众到した絬果（未発 衣）上もよく一致している。また $b^{\prime}$ と産卵率あるいは産

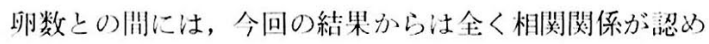

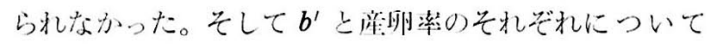

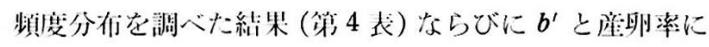

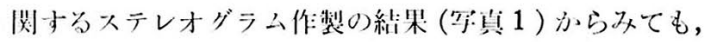

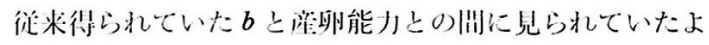

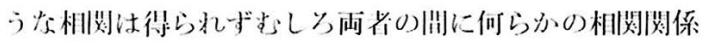

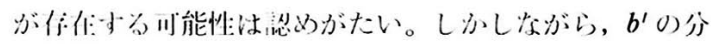

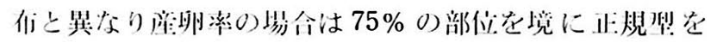
舭断した形の断崔状の分布を示していたことから，現時 点で实用産卵鷄として飼喰されている多くのものはすで に産卵性向上のために過去において相当に強い選抜をう 


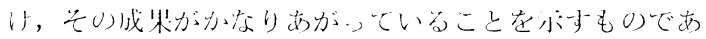
ろう。そしてある一走の水準末で汢それを机引上げうる が，その水準以上になると巽抜の効果を抑制するような 要因が介在证ることも考えられ，それがこのような特異 的分布形態となって現われたとも推測される。

一方, $b^{\prime}$ の平均值以下の個体群において産卵開始前に 死亡一る個体が多く出現与るのが羿められているが，本 実験では雛の死因等の細目にわたる調查を行なっていな いので特定の疾病との関連性を言及し得ない。しかし子 でに筆者が血清ビテリン伩忘回帰係数 $b$ についてとの值 の小なる群に死亡鷄が多発し $b$ の值によって段階的にグ ループ分けした群と死し率の相関は -0.879 と極めて高 い值を示したことならびにとの死亡鵎の大半がリンパ腫 症によるものであったと言う以前の結果 ${ }^{3}$ と考え合せる と血清ビデリン産生能としての $b$ あるいは $b^{\prime}$ の值と踓 病性との間に何らかの関連のあることが想像される。

またこれとは別に，すでにbの值によって高低 2 方向 に選抜交配を実施する目的でエストロジェン投与を施し た雄雛について, 性成熟後(150日龄以降)に打ける精巣 機能军組織学的な観察法により調べたところ

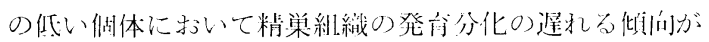

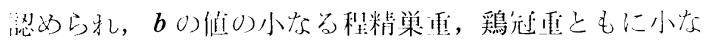

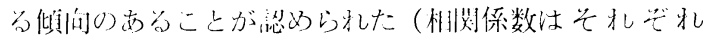

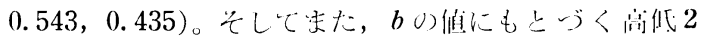

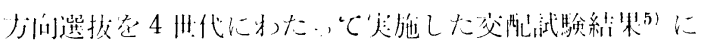

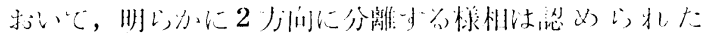

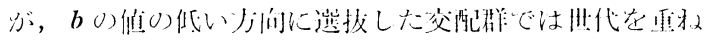

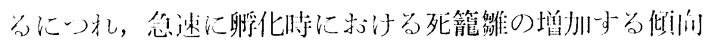

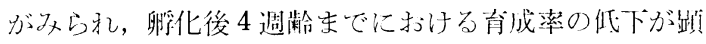
著であった。同時にbの值の高い交配群ではさらに世代 を重䄈ることが可能であるのに対して $b$ の值の低い交配 群では種雄鶏として残した試験䳕において精液採取不能 あるい注精液量のきわめて少い個体が絩出し，事笑上繁 殖を継繶することが不可能となった。

上記の種々の結果定総括して考えると, 体質的に证常 夻生理的機能または繁殖的機能を有子る個体は，性别に 閔係なく $b$ あるいは $b^{\prime}$ の值が中位あるいは中位以上け個 体ではないかと考光られる。また産卵成縝の面から多て

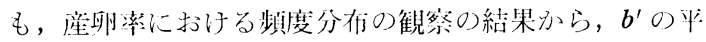

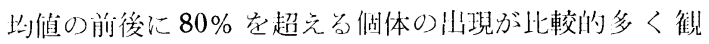

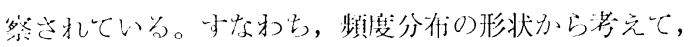

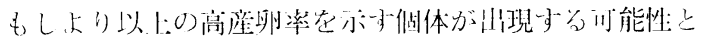
しては，統棓的な期待頻度という面から及ても $b^{\prime} 0 \%$ 均值附近により多く現われることが推測される。

要するに，エストロジェン投与による血清ビテリン産 生能の強弱と産卵性に関与古る幾つかの実用的形質との

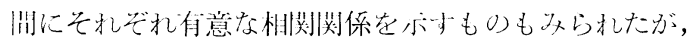
血清ビテリン産生能としてのb扩よび $b^{\prime}$ 沈さしろ投与ホ ルモンに対する個体の代射能力と密接に閔係するものと 考えられる。与なわち, 個体の生理的機能の状態あるい は正常な機能を有する個体の判定に対して有效な一指標 として重要な意笺をもつのではないかと考慮される。

今後さらに, 雄における精巣の発育分化および死亡䳕 の死因等安詳細に追究することは, 血清ビテリン産生能

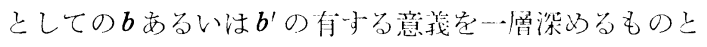
思われ 湌咕㠶ある。

\section{要 約}

彷来, 報告して来たェストロジェン投与雛におおる血。 清ビテリン産生能としての血清ビテリン反忘回㷌係数 $b$ 抢よ゙゙その代替簡便法としてのアセトン処理による混濁 度から得た回州係数 $\boldsymbol{b}^{\prime}$ が, 舀の種々の実用形質とどの ように関連するか子明らかにする為に本実験を行なっ た。また同時に血清ビテリン産生能が実用䳕育種上いか なる意義を有与るかについても考察した。

供試鵎としては, $\operatorname{Rapp}(\mathrm{Ra})$, Forsgate(Fo), Thorn$\operatorname{ber}(\mathrm{Th}), \operatorname{Garber}(\mathrm{G})$ の 4 系統の白他レグホーン種此知倠

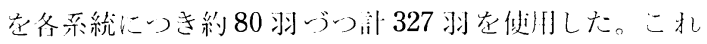

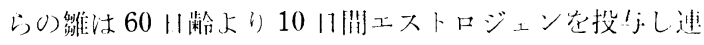

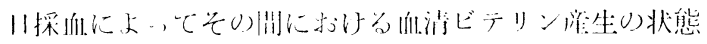

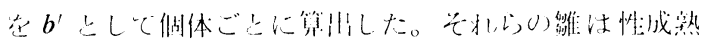

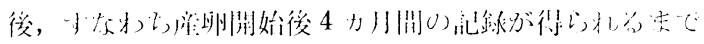

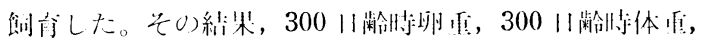

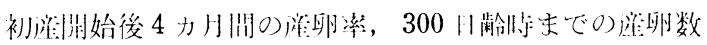
および初産山崩等の形啠を選九で $b^{\prime}$ との侧係について

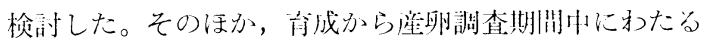
死亡数の調査を行ない, その絬果についても検都を扣光 た。

産卵諸形質について系統ごとに最小白乘平均值尤水

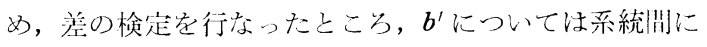
全く全が恋められなかったが，その他の形質については 系統により有意差が認められた。またそれらの形質間相 互の相䦥を求めてみると $b^{\prime}$ と卵重，体重柇よび初産日齿令

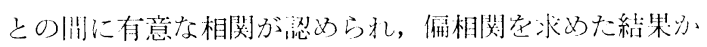

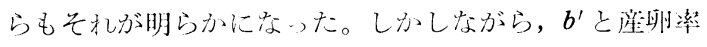

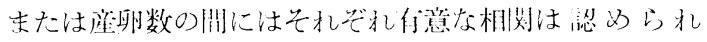

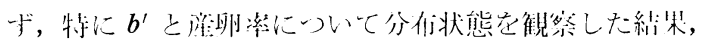

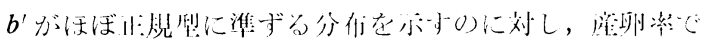

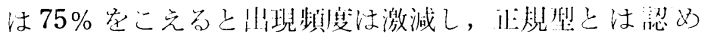
難い異常な分布を示していた。としてまた， b の平均值

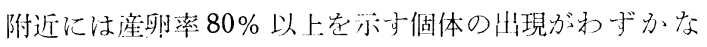
がら観察された。 
一方試験鷄の中には $b^{\prime}$ の値の低いものに死亡与る個 体の出現が多く, $x^{2}$-検定結果もきわめて有意であった。

以上の種々の結果から考察して, $b^{\prime}$ の值が直接, 種々 の実用形質との間に何らかの相関関係の認如られたもの もあったが，そ机より汢むしろがの值として示された血 清ビテリン産生能注, 個体の生理的機能と密接に関与 し，正常な機能を有する個体の判定に対して有効な一指 標として重要な意義を有することが示唆された。

\section{引用 文 献}

1）山本興三郎，河野憲太郎，樋浦善敬：日畜会報， 44, 315, 1973.

2）山本興三郎，中川忠雄：日畜会報, 36, 358, 1965.

3) Үамамото, K.: The Memoirs of the Faculty of Agriculture, Niigata University, 7, 87, 1968.

4) 山本興三郎, 河野憲太郎, 中島映子, 中川忠雄, 森沢佐歳：新潟農林研究，17, 7, 1965.

5）山本興三郎，河野憲太郎：日畜会報， 39，30， 1969. (学:会号)

\title{
The Relationship between some Productive Traits in Laying Hen and the Serum Vitellin Producibility in Estrogen Administered Chickens, and its Viewpoint for Poultry Breeding
}

\author{
Kozaburo Yamamoto, Koichi Yamagishi, Kentaro Kono and Yoshitaka Hiura \\ Faculty of Agriculture, Niigata University, Niigata-shi, 950-21
}

The purpose of this experiment was to clarify the relationship between the serum vitellin producibility in estrogen administration and a few productive traits in laying hen i.e. the serum vitellin producibility was represented as $b$ (the serum vitellin reaction regression coefficient) or b' (the regression coefficient calculated with the turbidities which was obtained from acetone precipitate of serum). Simultaneously, in this paper, the significance of the serum vitellin producibility at the viewpoint of poultry breeding was discussed.

Four strains (Rapp, Forsgate, Thornber and Garber) of White Leghorn chicken were employed in this experiment, and the total of them amounted to 327 birds (about 80 chickens in each strain). Estrogen abministration of $0.4 \mathrm{mg}$ in daily does was practiced from 60 days of age and continued for 10 days. Blood sera collected from the chicken every day were used for observation of turbidity, and the regression coefficients (b') were estimated from the turbidity individually.

Thereafter, they were reared for 4 months from the beginning of egg production and the records of egg laying were brought together.

The relationships among the b', the egg weight at 300 day old, the body weight at 300 day old, the rate of egg laying for 4 months after the first egg, the number of egg laying to 300 day old and the age at first egg were examined each other.

Least square means of each strain about the productive traits as above mentioned were estimated and Duncan's multiple range tests were employed to make all pairwise comparisons. The differences among strains for $b$ ' were non-significant, but significant in other traits.

The correlations between the b' and the egg weight or the body weight at age of 300 days or also the age at first egg were significant, and these relations became more evident from the estimates of the partial correlations among each trait. However, the correlations be- 
tween the b' and the rate of egg laying or the number of egg laying were non-significant respectively. Particularly, judging from the modes of frequency distribution as a bivariate normal population in regard to the b' and the rate of egg laying, it was unable to be considered as a normal distribution on account of the remarkable decrease of frequency of hen above $75 \%$ in the distribution of the rates of egg laying, as compared with the b' to be accepted as the random samples from a normal distribution. But, a small number of laying hen above $80 \%$ in the rate of egg laying was observed near the mean value of b'.

On the other hand, the higher mortalities were observed in the groups showed low value in b' and the result of chi-square test was highly significant.

From the results as above mentioned and various results during the past ten years, the correlations between the b' and some of the productive traits were recognized. However, it was suggested that the serum vitellin producibility represented as $b$ or $b$ ' had close relation to physiological function in individual chicken and was an available guide for the detection of normal chicken in physiological function. (Japan. Poultry Sci., 14, 131 137, 1977) 